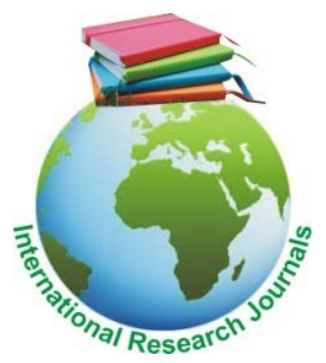

African Journal of Food Science and Technology (ISSN: 2141-5455) Vol. 9(3) pp. 52-58, Nov, 2018 DOI: http:/dx.doi.org/10.14303/ajfst.2018.236

Available online https://www.interesjournals.org/food-science-technology.html

Copyright (C2018 International Research Journals

Full Length Research Paper

\title{
Control strategy against fungal pathogens of postharvest rot of groundnut (Arachis hypogaea L.) using aqueous and ethanol leaf extracts of mahogany (Khaya senegalensis) in hong local government area of Adamawa state, Nigeria
}

\author{
Channya FK*, Asama P, Anjili SM \\ Department of Plant Science, Modibbo Adama University of Technology, Yola, Nigeria \\ farbinah222@gmail.com
}

\begin{abstract}
Fungi are associated with heavy losses of seeds, fruits, grains, vegetables and other plant products in transit and storage rendering them unfit for human consumption. The used of synthetic fungicide has a great effect on human consumption, hence the need for safer control. A research was conducted in Hong local government area of Adamawa State of Nigeria (the most prominent groundnut farming community in the state). The following moulds were associated with postharvest groundnut rot in the seven districts of Hong local government area in the month of July 2016: Aspergillus niger (brasilensis), Aspergilus flavus, Penicillium chrysogenum, Rhizopus stolonifer, Paecilomyces lilacinus, Pseudallescheria boydii, Cylindrocarpon lichenicola and Scedosaporium prolificans. Therefore, the research sought to assess management of rot using plant extract of mahogany. Control trials were carried out using the extracts of leaf of mahogany. Growth of pathogens both in-vitro and in-vivo were significantly reduced by the plant extracts. Aqueous and ethanol leaf extracts reduced mycelial growth from $72.67 \mathrm{~mm}$ to $25.83 \mathrm{~mm}$ and $15.33 \mathrm{~mm}$ respectively for Aspergillus niger (brasilensis) (in-vitro) and from $55.00 \mathrm{~mm}$ to $28.58 \mathrm{~mm}$ by aqueous extracts and to $17.92 \mathbf{~ m m}$ size of rot by ethanol extracts for in-vivo control. Efficacy of extract increased with concentration, while the local genotype was less affected by rot in comparison to Kampala variety. Therefore, mahogany aqueous and ethanol leaf extracts have been found effective against these pathogens and therefore the leaf is recommended for further research in order to formulate a control strategy for these pathogens.

Keywords: Control, Groundnut, Fungi, Mahogany.
\end{abstract}

\section{INTRODUCTION}

The roles of agriculture remain significant in the Nigerian economy despite the strategic importance of the oil sector, agriculture still provides primary means of employment for Nigeria and accounting for more than one third of total Gross Domestic Product (GDP) and labour force (Ayoade, 2012).

The major food crops of Adamawa State according to Adebayo (1997) are mainly cereals, legumes and root crops, while the cash crops are mainly cotton, groundnut and sugar cane. The variable climatic and edaphic factors of the state as well as cultural and socio-economic factors are reportedly responsible for the distribution of food and cash crops in the State.

In the North-East zone of Adamawa State, groundnut is a major cash crop produced especially in Hong (Adebayo and Tukur, 1999). Rowland (1999) reported that seed yield in Northern Nigeria is about $3000 \mathrm{Kg} / \mathrm{ha}$. Adamawa Agricultural Development Programme, ADADP (1996) enumerated groundnut genotypes commonly grown in Adamawa State to include; "Ordaaji"; (2 nuts/shell), "Kwamakuni"; (3 nuts/shell), "Kwathrumthrum"; (2 nuts/ shell larger), "Kwanyambi" or Ex Dakar and Kampala (brown/white striped nuts).

Groundnut (Arachis hypogaea L.) is an important oil seed crop in Nigeria and is widely grown in the tropics 
and sub-tropics (Nigam et al., 1994). It is one of the most important crops that have the ability to thrive on newly reclaimed sandy soils as a legume of high nutritive value as well as being a source of edible oil (Spears et al., 2002). The major groundnut producing countries from the world are China, India, Nigeria, Argentina, USA, Indonesia, and Sudan. Developing countries account for 96 per cent of the global groundnut area and 92 per cent of the global production (FAOSTAT, 2011).

Fungi such as Aspergillus niger (brasiliensis), Aspergillus flavus, Alterneria anthocola, Curvularia lunata, Curvulari apellesecens, Fusarium oxysporum, Fusarium equiseti, Microphomina phaseolina, Rhizopus stolonifer, Penicillium digitatum and Penecillium chrysogenum cause severe damage to stored commodities resulting in discolouration, rotting, shrinking, seed necrosis, loss in germination capacity and toxification to oil seeds (Chavan and Kakde, 2008). These fungi are associated with heavy loss of seeds, fruits, grains, vegetables and other plant products during picking, transit and storage rendering them unfit for human consumption even by producing mycotoxins and affecting their total nutritive value (Verma et al., 2003). The tropical climate with high temperature and high relative humidity along with poor storage methods adversely affect the storage of cereal grains and oil seed, and this can lead to the total loss of seed quality (Bhattacharya and Raha, 2002). Groundnut seed is susceptible to a wide range of pathogens and pests which cause a lot of damage to the crop, thereby reducing yield (Weiss, 2000).

Therefore, many of the seed-borne fungi were generally managed by the use of some synthetic chemicals which were also considered to be both efficient and effective (Ahmed et al., 2012). The continuous use of this fungicides unraveled its non-biodegradability and leaving a residual toxicity to cause environmental pollution (Ajobade and Amusa, 2001), hence the need for alternative safer means of control.

In recent years, much attention has been given to the use of non-chemical systems for the treatment of the seed in order to protect it against plant pathogens (Ademola et al., 2004). Plant extracts have played significant role in inhibiting of seed-borne pathogens, improving seed quality and emergence of plant seeds (Abdelgaleil et al., 2004). There is now emphasis on use of botanicals such as the flowers, cloves, leaves, bark, root and seed extracts which are considered as cheaper and safer means of mould control (Abdelgaleil et al., 2001). Alternative ways to control seed-borne pathogens, particularly using extracts of medicinal plants are novel, phytochemically and pharmacologically (Sofowora et al., 2013), Khaya senegalensis as a source of bio-pesticides in tropical and subtropical Africa, is perhaps the most promising because it possesses nearly all characteristics of an ideal bio-pesticides agent currently attracting research interest worldwide.

A good solvent in plant extraction should be of low toxicity, ease of evaporation at low heat, promotion of rapid physiologic absorption of the extract, preservative action and inability to cause the extract to complex or dissociate (Hughes, 2002). Thus the most commonly used solvents for preliminary investigations of anti-microbial activity in plants are said to be methanol, ethanol and water (Lourens et al., 2004; Parekh et al., 2006).

The aim of the study was to determine the inhibitory effect of aqueous and ethanol leaf extracts of Khaya senegalensis on post-harvest fungal pathogens of groundnut rot obtained from the seven districts of Hong Local Government Area of Adamawa State.

\section{METHODS AND MATERIALS}

The control with root extracts was conducted in the Medical Laboratory of Microbiology Department, Modibbo Adama University of Technology (MAUTECH) Yola, from $18^{\text {th }}$ July 2016 to $24^{\text {th }}$ October 2016.

\section{Source of Groundnut Samples}

Samples of groundnut seeds of two genotypes commonly found namely Kampala and "Kwathrumthrum" were collected from one major market in each of the seven districts namely Hildi, Kulinyi, Dugwaba, Uba, Gaya, Pella and Hong (Table 1). Fifty of the samples of each genotype were purchased from a seller (two randomly selected sellers/traders within the selected market) in each district making a total of 700 collected from the various district, the samples were conveyed to the laboratory in a dry clean polythene bag. Groundnut samples were labelled according to location and then photographed (Figures 1-5).

Table 1. Groundnut Varieties used for the Study

\begin{tabular}{|c|c|c|c|c|c|}
\hline No & Subspecies & Variety & $\begin{array}{c}\text { Botanical } \\
\text { types }\end{array}$ & $\begin{array}{c}\text { Seed coat } \\
\text { colour }\end{array}$ & $\begin{array}{c}\text { Pod } \\
\text { sizes }\end{array}$ \\
\hline 1 & fastigiata & Kampala & Valencia & $\begin{array}{c}\text { Brown -white } \\
\text { (var) }\end{array}$ & $3-4 \mathrm{~cm}$ \\
\hline 2 & hirsuta & Kwathrumthrum & Peruvian & Brown & $3-4 \mathrm{~cm}$ \\
\hline
\end{tabular}

\section{Sterilization of Inoculation Room and Instruments}

Sterilization of laboratory environment was carried out in order to avoid contamination. The bench and tables used for inoculation were swapped clean using 95\% ethanol and UV light switched on for 30 min before carrying out inoculation. Petri- dishes were sterilized at $160^{\circ} \mathrm{C}$ for 1 $\mathrm{h}$ in the oven, forceps and needles used for inoculation were sterilized by flaming on a Bunsen burner flame and dipping into methylated spirit to cool. 


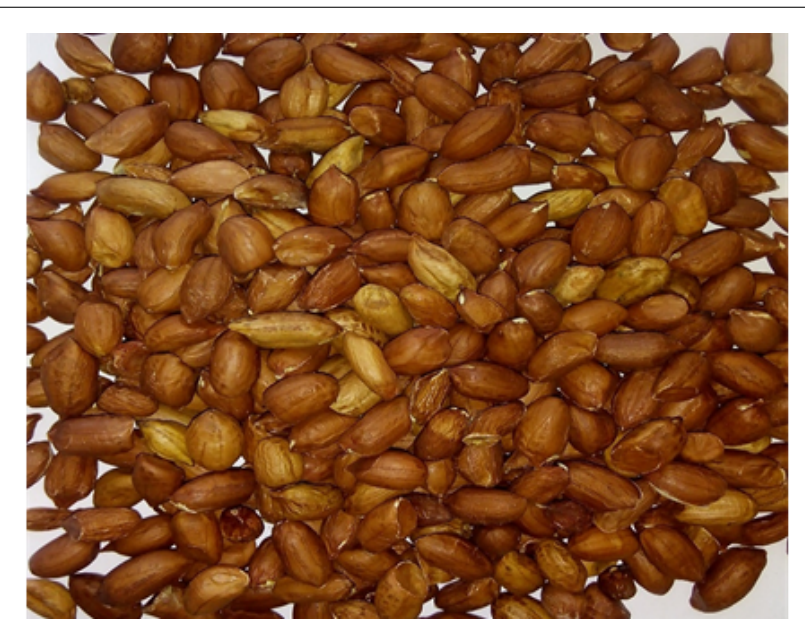

Figure 1. Sample of Healthy "Kwathrumthrum" Variety Groundnut Seeds

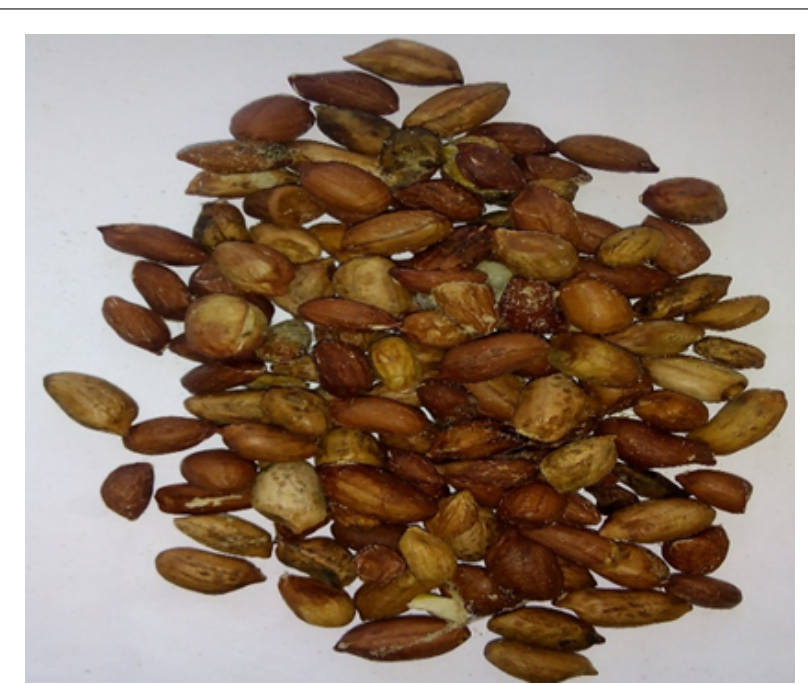

Figure 2. Sample of "Kwathrumthrum" Variety Diseased Groundnut Seeds

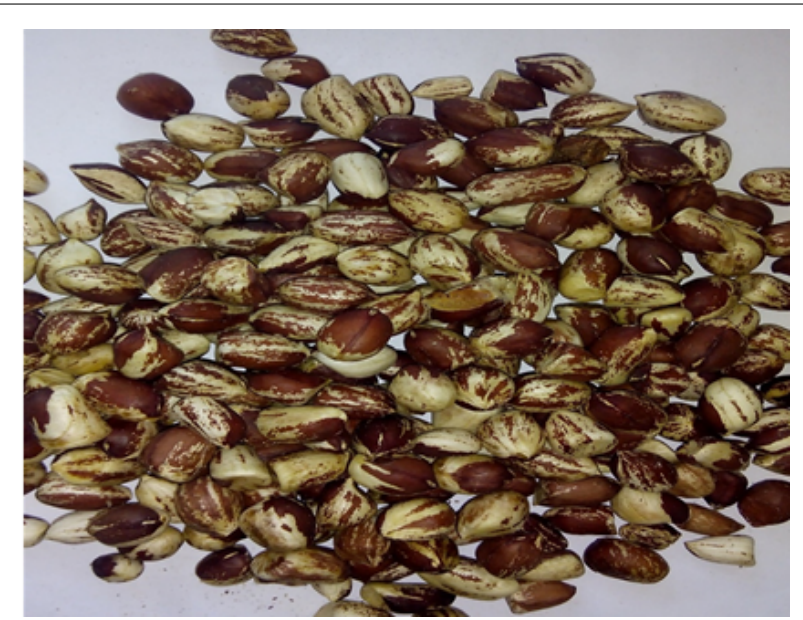

Figure 3. Sample of Healthy Kampala Variety Groundnut Seeds

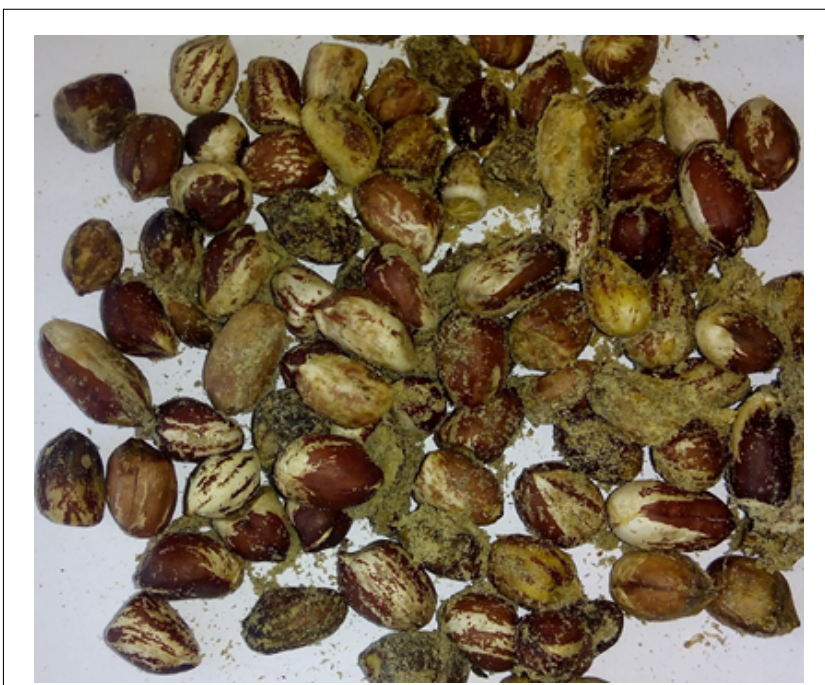

Figure 4. Sample of Diseased Kampala Variety of Groundnut Seeds

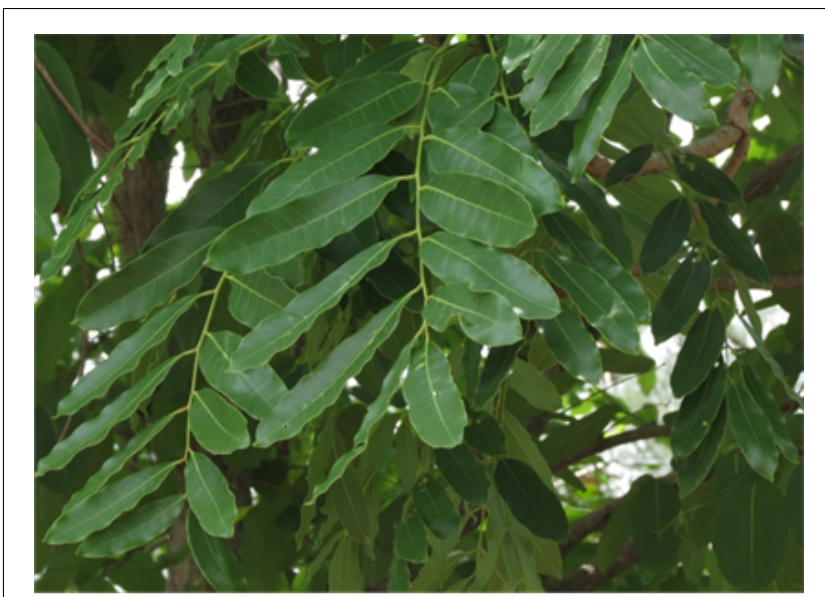

Figure 5. Khaya senegalensis Leaf

\section{Preparation of Potato Dextrose Agar (PDA)}

Thirty nine grams (39 g) of Potato Dextrose Agar (PDA) was dissolved in one $1 \mathrm{~L}$ of distilled water, the potato dextrose agar was then poured into two $500 \mathrm{~mL}$ conical flask, then plugged with cotton wool and wrapped with aluminium foil before autoclaving at $121^{\circ} \mathrm{C}$ for $15 \mathrm{~min}$ at $10 \mathrm{lbs}$. pressure, and $6 \mathrm{~mL}(0.1 \%)$ of streptomycin was added to the litre of sterilized media and swirled gently to mix properly, just before pouring into Petri dishes to prevent bacterial growth and allowed to cool and solidify according to the method of Suleiman and Michael (2013).

\section{Collection and Preparation of Extracts}

The method of ljato et al. (2011) was used to prepare both aqueous and ethanol extracts. Fresh leaves of Khaya senegalensis were collected from General Murtala Mohammed College Jimeta-Yola, Adamawa State. The collected leaves were rinsed thoroughly under running tap 
water (Figure 3) and were allowed to air dry for 7 days, these were then ground using pestle and mortar. Hundred (100) g, sixty (60) g and twenty (20) g were dissolved in sterile distilled water and ethanol in separate conical flasks respectively. These were vigorously shaken and left to stand for $24 \mathrm{~h}$. The samples were then filtered with 3 layers' cheese cloth. The crude aqueous and ethanol extracts were evaporated through heating with hot plate to complete dryness and concentrations of $100 \%, 60 \%$ and $20 \%$ were used.

\section{Effect of Leaf Extract on the Isolates}

The in-vitro test was carried out using the approach of ljato (2011) to evaluate the effect of the extract on fungal colony growth by creating four equal sections on each plate by drawing two perpendicular lines at the bottom of the plate. The point of intersection indicates the centre of the plates. This was done before dispensing the PDA mixed with the aqueous and ethanol leaf extracts into each of the plates in the different concentrations of $100 \%, 60 \%$, and $20 \%$ (pour plate method) followed by inoculation of the isolate. Control experiment was without addition of any mahogany leaf extract. Growth inhibition was determined by ruler measurements of radial colonial expansion.

The in-vivo test was carried out by placing cotton wool onto the plates then placing three healthy seeds before inoculating mycelial/spore suspension of each of the pathogens unto the seeds and also 2 drops of the extracts (aqueous and ethanol) with sterile syringe. Fungal growth inhibition was determined by measuring growth of fungus with measuring ruler $(\mathrm{mm})$.

\section{Statistical Analysis}

All the data were analyzed using Analysis of Variance (ANOVA) according to Gomez and Gomez (1984). Least Significant Difference (LSD) according to Scheff (1953) was used to separate the means that were significantly different. Statistical Analysis Software (SAS) Version 9.1 was used to analyze the results.

\section{RESULTS}

\section{In-vitro and In-vivo Aqueous and Ethanol Control}

Leaf extract of mahogany effectively controlled the mycelial growth of the pathogens compared to control (Table 2). Both aqueous and ethanol leaf extracts most effectively controlled Scedosporium prolificans (colony size of $12.96 \mathrm{~mm}$ for aqueous and $11.04 \mathrm{~mm}$ for ethanol), Pseudaiiescheria boydii with $13.21 \mathrm{~mm}$ for aqueous and $9.25 \mathrm{~mm}$ for ethanol, Cylindrocarpon lichenicola 13.25 $\mathrm{mm}$ for aqueous and $11.58 \mathrm{~mm}$ for ethanol extract, Paecilomyces lilacinus $13.58 \mathrm{~mm}$ for aqueous and 11.54 $\mathrm{mm}$ for ethanol, Penicillium chrysogemuni $18.58 \mathrm{~mm}$ for aqueous and $11.96 \mathrm{~mm}$ for ethanol, and Aspergillus brasilensis with $25.83 \mathrm{~mm}$ for aqueous and $15.33 \mathrm{~mm}$ for ethanol. There was however no significant difference in efficacy between the two solvents in control of these pathogens. In comparison, leaf extract had less inhibition on the colony expansion of Rhizopus stolonifer (28.88 $\mathrm{mm}$ for aqueous, $20.58 \mathrm{~mm}$ for ethanol), Aspergillus flavus (26.63 $\mathrm{mm}$ aqueous, $15.46 \mathrm{~mm}$ for ethanol). There was a significant variation in growth inhibition (in-vitro) by the leaf extract between the solvents on Aspergillus niger, Aspergillus flavus, Penicillium chrysogenum and Rhizopus stolonifer.

The in-vivo leaf extract of mahogany showed that there was a significant inhibitory effect on all the pathogens of groundnut postharvest rot in Hong Local Government Area of Adamawa State, Nigeria. Similar trend in efficacy was exhibited as in the in vitro control. There was less rot in seeds inoculated with the following pathogens: Scedosporium prolificans (16.79 mm for aqueous, 15.38 $\mathrm{mm}$ for ethanol), Paecilomyces lilacinus (17.92 $\mathrm{mm}$ for aqueous, $13.63 \mathrm{~mm}$ for ethanol), Pseudaiiescheria boydii

Table 2. Effect of Aqueous and Ethanol Leaf Extracts of Khaya senegalensis on Colony Expansion (mm) and Rot of Fungal Pathogens of Stored Groundnut in Hong Local Government Area of Adamawa State, Nigeria.

\begin{tabular}{|c|c|c|c|c|c|c|c|c|}
\hline \multicolumn{9}{|c|}{ Pathogens } \\
\hline & $\begin{array}{l}\text { Aspergillus } \\
\text { brasilensis }\end{array}$ & $\begin{array}{l}\text { Aspergillus } \\
\text { flavus }\end{array}$ & $\begin{array}{l}\text { Penicillium } \\
\text { chrysogenum }\end{array}$ & $\begin{array}{l}\text { Rhizopus } \\
\text { stolonifer }\end{array}$ & $\begin{array}{l}\text { Pseudaiiescheria } \\
\text { boydii }\end{array}$ & $\begin{array}{l}\text { Paecilomyces } \\
\text { lilacinus }\end{array}$ & $\begin{array}{l}\text { Cylindrocarpon } \\
\text { lichenicola }\end{array}$ & $\begin{array}{l}\text { Secdosporium } \\
\text { prolificans }\end{array}$ \\
\hline \multicolumn{9}{|c|}{ In-vitro (mycelial growth in $\mathrm{mm}$ ) } \\
\hline \multicolumn{9}{|l|}{ Solvents } \\
\hline Aqueous & 25.83 & 26.63 & 18.58 & 28.88 & 13.21 & 13.58 & 13.25 & 12.96 \\
\hline Ethanol & 15.33 & 15.46 & 11.96 & 20.58 & 9.25 & 11.54 & 11.58 & 11.04 \\
\hline Control & 72.67 & 68 & 65.33 & 88.67 & 60.67 & 64 & 67.33 & 85.33 \\
\hline LSD & 4.82 & 9 & 6.46 & 6.81 & 6.16 & 2.74 & 5.29 & 4.58 \\
\hline \multicolumn{9}{|c|}{ In-vivo } \\
\hline Aqueous & 28.58 & 35.79 & 24.5 & 41.08 & 16.04 & 17.92 & 20.17 & 16.79 \\
\hline Ethanol & 17.92 & 18.46 & 12.58 & 24.13 & 11.33 & 13.63 & 13.17 & 15.38 \\
\hline Control & 55 & 55 & 42.5 & 78.33 & 34.17 & 43.33 & 44.17 & 42.5 \\
\hline LSD & 3.92 & 3.53 & 3.92 & 5.59 & 2.59 & 3.31 & 4.82 & 3.59 \\
\hline
\end{tabular}

LSD: Least Significant Difference 
(16.04 $\mathrm{mm}$ for aqueous, $11.33 \mathrm{~mm}$ for ethanol), and Cylindrocarpon lichenicola $(20.17 \mathrm{~mm}$ for aqueous and $13.17 \mathrm{~mm}$ for ethanol). There was however no significant difference in efficacy between the two solvent extracts of mahogany leaf. The three most notorious pathogen exhibited higher rot in comparison to these other pathogens Rhizopus stolonifer (41.08 mm aqueous, 24.13 $\mathrm{mm}$ for ethanol), Aspergillus flavus (35.79 mm aqueous, $18.46 \mathrm{~mm}$ ethanol) and Aspergillus niger (brasilensis) (28.58 $\mathrm{mm}$ for aqueous, $17.92 \mathrm{~mm}$ for ethanol). Ethanol leaf extract was more effective in reducing rot incited by these pathogens than the aqueous leaf extract.

The concentration levels in the in vitro control showed there was a significant difference among them and the most effective was produced in $100 \%$ concentration followed by $60 \%$ concentration, least was the $20 \%$ concentration (Table 3).

Similarly, the higher the concentration the more effective the extract control on the rot, with $100 \%$ concentration having a higher inhibitory effect then $60 \%$ concentration followed by $20 \%$ concentration (Table 3 ) in the in vivo control trial.

There was a high variation between the Kampala and Local (Kwathrumthrum) genotypes, growth of pathogens was reduced more in the Local (Kwathrumthrum) genotype than the Kampala variety by the extract at $9.99 \%$. The lowest growth was recorded in the Local (Kwathrumthrum) genotype with Pseudaiiescheria boydii had $8.75 \mathrm{~mm}$, Cylindrocrpon lichenicola $(10.17 \mathrm{~mm})$, Scedosporium prolificans (10.38 mm), Penicillium chrsogenum (10.83 $\mathrm{mm})$, Paecilomyces lilacinus (12.17 mm), Aspergillus niger (16.00 mm), Aspergillus flavus (16.25 mm), and Rhizopus stolonifera $(20.38 \mathrm{~mm})$ while for the Kampala variety Pseudaiiescheria boydii had $18.63 \mathrm{~mm}$, Paecilomyces lilacinus (19.38 mm), Scedosporium prolificans (21.79 $\mathrm{mm})$, Cylindrocarpon lichenicola (23.17 mm), Penicillium chrysogenum (26.25 mm), Aspergillus niger (brasilenesis) (30.50 mm), Aspergillus flavus (38.00 mm) and Rhizopus stolonifer (44.83 mm) (Table 4).

\section{DISCUSSION}

The study indicates that 'kwathrumthrum' (local genotype) exhibited a higher resistance to all the eight postharvest groundnut rot fungal pathogens. This can be as a result of resistance exhibited by the host which is in agreement with the work of Hasyim et al. (2015) who reported that host plant resistance is considered as one of the most important disease control strategies.

Both aqueous and ethanol leaf extracts of mahogany are effective control agents on all the postharvest fungal pathogens of groundnuts both in vitro and in vivo, though efficacy varied with pathogens. This agrees with reports (Lourens et al., 2004, Parekh et al., 2006, Rojas et al.,

Table 3. Inhibitory Effect of Different Concentration of Leaf Extracts on Fungal Pathogens in Hong Local Government Area of Adamawa State, Nigeria.

\begin{tabular}{|c|c|c|c|c|c|c|c|c|}
\hline \multicolumn{9}{|c|}{ Pathogens } \\
\hline & $\begin{array}{c}\text { Aspergillus } \\
\text { niger }\end{array}$ & $\begin{array}{c}\text { Aspergillus } \\
\text { flavus }\end{array}$ & $\begin{array}{c}\text { Penicillium } \\
\text { chrysogenum }\end{array}$ & $\begin{array}{l}\text { Rhizopus } \\
\text { stolonifer }\end{array}$ & $\begin{array}{c}\text { Pseudaiiescheria } \\
\text { boydii }\end{array}$ & $\begin{array}{c}\text { Paecilomyces } \\
\text { lilacinus }\end{array}$ & $\begin{array}{l}\text { Cylindrocarpon } \\
\text { lichenicola }\end{array}$ & $\begin{array}{c}\text { Secdosporium } \\
\text { prolificans }\end{array}$ \\
\hline \multicolumn{9}{|c|}{ In-vitro (mycelial growth in mm) } \\
\hline \multicolumn{9}{|c|}{ Concentration (\%) } \\
\hline 20 & 13.17 & 15.17 & 8.67 & 9.83 & 5.5 & 3.75 & 3 & 3.17 \\
\hline 60 & 8.5 & 8.17 & 6.08 & 6.75 & 3 & 2.08 & 1.67 & 1.5 \\
\hline 100 & 5.67 & 5.83 & 3.83 & 4 & 2.25 & 1.08 & 0.83 & 0.83 \\
\hline LSD & 6.82 & 12.74 & 9.14 & 9.63 & 8.71 & 3.87 & 7.48 & 6.48 \\
\hline \multicolumn{9}{|c|}{ In-vivo } \\
\hline \multicolumn{9}{|c|}{ Concentration (\%) } \\
\hline 20 & 19.5 & 27 & 15.83 & 26.25 & 10.67 & 10.5 & 11.5 & 11 \\
\hline 60 & 12.92 & 18 & 11.25 & 18.25 & 7.58 & 6.75 & 8.42 & 7.67 \\
\hline 100 & 5.83 & 8.5 & 4.58 & 7.58 & 2.33 & 2.5 & 2.58 & 3.17 \\
\hline LSD & 5.55 & 4.99 & 5.54 & 7.91 & 3.66 & 4.68 & 6.82 & 5.08 \\
\hline
\end{tabular}

LSD: Least Significant Difference

Table 4. Effect of Leaf Extract on Mycelial Growth of Fungal Pathogens of Stored Groundnut Genotypes (mm) in Hong Local Government Area of Adamawa State, Nigeria.

\begin{tabular}{|c|c|c|c|c|c|c|c|c|}
\hline & $\begin{array}{c}\text { Aspergillus } \\
\text { niger }\end{array}$ & $\begin{array}{c}\text { Aspergillus } \\
\text { flavus }\end{array}$ & $\begin{array}{c}\text { Penicillium } \\
\text { chrysogenum }\end{array}$ & $\begin{array}{c}\text { Rhizopus } \\
\text { stolonifer }\end{array}$ & $\begin{array}{c}\text { Pseudaiiescheria } \\
\text { boydii }\end{array}$ & $\begin{array}{c}\text { Paecilomyces } \\
\text { lilacinus }\end{array}$ & $\begin{array}{c}\text { Cylindrocarpon } \\
\text { lichenicola }\end{array}$ & $\begin{array}{c}\text { Scedosporium } \\
\text { prolificans }\end{array}$ \\
\hline Variety & & & & & & & \\
\hline Kampala & 30.5 & 38 & 26.25 & 44.83 & 18.63 & 19.38 & \\
\hline Local & 16 & 16.25 & 10.83 & 20.38 & 8.75 & 12.17 & 23.17 & 10.17 \\
\hline LSD & 3.92 & 3.53 & 3.92 & 5.59 & 2.59 & 3.31 & 10.38 \\
\hline
\end{tabular}

LSD: Least Significant Difference 
2006) that both aqueous and ethanol were effective solvents for preliminary investigations against microbial activity. Meanwhile, ethanol was more effective than aqueous, this could be as result agents present in ethanol capable to dissolve the active component in the plant extract. It also conforms with the work of Shehu et al. (2016) aqueous (water) is an inorganic solvent which may not be effective to dissolved the bioactive compounds responsible for antifungal and antimicrobial activities.

Efficacy of the extracts appreciated with the level of concentration which conforms to report by Green (2004) that higher sample ratio to solvent was ideal for control. The best and ideal concentration of mahogany root extract is $60 \%$ since it exhibits similar efficacy with $100 \%$. The result was also in agreement with the work of Abdulsalam et al. (2015) who report that treatment with different concentrations of Mahogany can retard the vegetative growth of fungi responsible for neck rot disease of onions and also in line with the work of Liman et al. (2010) who reported the effect of Mahogany plant in the control of fungi and nematodes. The result is also in agreement with the work of Shehu et al. (2016) who reported that leaf extract of the plant had inhibitory activity on mycelia growth of pathogenic fungi regardless of the extraction solvents and the concentrations of the extracts. Shehu et al. (2016) further stated that, the strong antifungal properties could be due to the fact that leaves are considered as the most important life giving part of the plant body, as they carry out the process of photosynthesis, therefore, the leaves are loaded with bioactive materials (Bareja, 2011).

\section{CONCLUSION}

The study revealed leaf extract of Mahogany has the potential to reduced fungal rot of groundnut seeds at different concentration and different solvent. Plant extracts are cheaper, safer, affordable to the farmer and environmental friendly, therefore, there is need for more researches into the use of plant extracts by pathologist. Farmers thus have hope for a cheaper and safer alternative control against deteriorating fungal agents of groundnut.

\section{REFERENCES}

Abdulsalam AA, Zakari BG, Chimbekujwo IB, Channya $\mathrm{FK}$ and Bristone B (2015). Isolation and control of fungi associated with neck rot disease of onions (Allium cepa L.) In bama, borno state, Nigeria. Global. J. Biol. Agri. Health. Sci. 4: 35-39.

Ademola IO, Fagbemi BO and Idowu SO (2004). Evaluation of the anthelmintic activity of Khaya senegalensis extract against gastrointestinal nematodes of sheep: In vitro and in vivo studies. Vet. Parasitol. 122(2): 151-164.

Abdelgaleil SAM, Okamura H, Iwagawa T, Sato A,
Miyihara I, Doe M, Nakatani M (2001). Khayanolides rearranged phragmalin limonoid antifeedants from Khaya senegalensis. Tetrahedron. 57(1): 119-126.

Adamawa Agricultural Programme ADADP (1996). Crop recommendation for extension workers in Adamawa state. 1-40.

Adebayo AA (1997). The agroclimatology of rice production in Adamawa State $\mathrm{PhD}$ thesis dept of Geography F.U.T. Minna, Nigeria. 78.

Adebayo AA, Tukur AE (1999). Adamawa State in map (Editor). Department, Geography, F.U.T. Yola ( $1^{\text {st }}$ eds) Paraclete publisher Yola, Nigeria, 33: 112

Ahmed Z, Saifullah Raziq F, Khan H and Idress M (2012). Chemical and biological control of fusarium root Rot of okra. Pak. J. Bot. 44(1): 453-457.

Ajobade TA, Amusa A (2001). Evaluation of antifungal efficacy of some plant extract on cusvularia. Lunate the causal organisms of leaf spot. Afr. J. Environ. Sci. Tech. 4(110): 797-800.

Ayoade AR (2012). Determinants of Climate Change on Cassava Production in Oyo State, Nigeria. Glob. J. Sci. Front. Res. Agri. Biol. 12(3): 44-50.

Bareja BG (2011). Light intensity in plant growth and development. Crops review.com.

Bhattacharya K and Raha S (2002). Deteriorative changes of maize, groundnut and soybean seeds by fungi storage. Mycopathologia.155: 135-141.

Chavan AM and Kakde RB (2008). Studies on abnormal oilseeds mycoflora from Marathwada region. Bionano Frontier. 2: 101-104.

FAOSTAT. (2011) Food and Agriculture Organization of the United Nations.

Gomez KA and Gomez AA (1984). Statistical procedures for agriculture research (3rd ed) 680. John Wiley and Sons. NewYork, 680.

Green RJ (2004). Antioxidant activity of peanut plant tissues. master's thesis. North Carolina State University, USA.

Hasyim A, Setiawati W and Liferdi L (2015). Technological innovation of sustainable pest and disease management on chili peppers: An alternative effort to establish harmonious ecosystem. Pengembangan Inovasi Pertanian. 8(1): 1-10.

Hughes I (2002). Science in Africa Magazine. 56.

Ijato JY, Otoide JE, Ijadunola JA and Aladejimokun AO (2011). Efficacy of antimicrobial effect of Venonia amygdalina and Tridax procumbens in in vitro control of 
tomato (Lycopersicum esculentum) post harvest fruit rot. Report and Opinion. 3(1): 120-123.

Liman IB, Ibrahim S and Rabah NT (2010). The efficacy of Mahogany leaf extract on Root knot nematode disease of tomato (Lycopersicon esculentum). Niger. J. Basic. Appl. Sci. 18(2): 272-276.

Lourens ACU, Reddy D, Başer KHC, Viljoen AM and Van Vuuren SF (2004). In vitro biological activity and essential oil composition of four indigenous south african Helichrysum species. J. Ethnopharmacol. 95: 253-258.

Nigam SN, Nageswara Rao RC, Wynne JC, Williams JH, Fitzner M, Nagabhushanam GVS (1994). Effect and interaction of temperature and photoperiod on growth and partitioning in three groundnuts (Arachis hypogaea L.) genotypes. Am. Appl. Bio.125: 541-552.

Parekh J and Chanda S (2006) In vitro antimicrobial activities of extract of Launaea procumbens Roxb. (Labiateae), Vitis vinifera (Vitaceae) and Cyperus rotundus (Cyperaceae). Afr. J. Biomed. Res. 9: 89-93.

Rojas JJ, Ochoa VJ, Saul AO and John FM (2006). Screening for antimicrobial activity of ten medicinal plants used in Colombian folkloric medicine: A possible alternative in the treatment of non-nosocomial infections. BMC. Complement. Altern. Med. 6: 2.

Rowland (1999). Profitability of groundnut production in Michika local government area of Adamawa State. Nigeria. J.Agric.Sci. 1(1):25-29.

Scheff H. (1953). A method of judging all contrast in the analysis of variance. Biometric. 40: 104-107.

Shehu H, Waziri AF and Musa AR (2016). Ethnomedicinal potential of Khaya senegalensis (Desr) A. Juss (Mahogany) on pathogenic fungi of vegetables in sokoto metropolis. Int. J. Appl. Chem. Pharm. Sci.1(1): 15-24.

Sofowora A, Eyitope O and Adedeji O (2013). THE Role and Place of Medicinal Plants in The Strategies for Disease Prevention. Afr. J. Tradit. Complement. Altern. Med. 10(5): 210-229.

Spears JF, Jordan DL and Bailey JE (2002). Groundnut seed production - A guide for producers of Virginia-type groundnut seed. NC.Coop. Ext.Serv.Bull. AG. 662: 1-7.

Suleiman MN and Michael AJ (2013). Bioactive Properties of Azadirachta indica and Cymbopogan citrates on Some Pathogens of Guinea Corn Seeds in Storage. Niger.J.Mycol. 5: 74-81.

Verma SS, Tomer RPS and Verma U (2003). Loss of viability and vigour in Indian mustard seeds stored under ambient conditions. Seed. Res. 31: 98-101.

Weiss EA (2000). Oilseed crops. In: Blackwell Science Ltd. ( $2^{\text {nd }}$ eds) Paris, Tokyo, Berlin, Victoria. pp. 317-364. 